\title{
Charcot-Leyden crystals and Curschmann spirals in asthmatic sputum
}

\author{
ALEX SAKULA
}

More than a century has elapsed since the microscopic examination of the sputum of asthmatic patients revealed characteristic crystals (so called "asthma crystals") and spirals, which are now referred to respectively as Charcot-Leyden crystals and Curschmann spirals.

This paper relates the story of their discovery, the eponymous personalities concerned, the development of our knowledge of these structures, and current views on their significance.

\section{Jean-Martin Charcot (1825-1893)}

Charcot (fig 1) was born in 1825 in Paris and in 1853 qualified MD Paris. Virtually throughout his entire career he was associated with the great Paris hospital the Salpetrière, where he served from 1848 as interne and from 1862 as physician. He was at the Salpetrière when it was bombed in 1871 during the FrancoPrussian war. Initially, morbid anatomy was his ruling passion and the lung one of his special interests; his description of the pulmonary lobule remains a classic. ${ }^{12}$ In 1872 he became professor of pathological anatomy. At the same time, however, he pursued his clinical studies, especially in the field of nervous diseases, in which his contributions to the knowledge of such conditions as tabes dorsalis, multiple sclerosis, and hysteria were outstanding. In 1882 he was appointed to a chair in neurology, the first of its kind in the world. His lecture demonstrations at the Salpetrière were famous and attracted students from afar, including Sigmund Freud in 1885. Charcot died of acute pulmonary oedema secondary to aortic valvular disease in $18933^{3}$

It was early in his career at the Salpetrière that Charcot, with Charles-Philippe Robin (1821-1885), published in 1853 a report on the pathological findings in a case of leukaemia (leucocythémie) in which blood taken from the right ventricle and also

Address for reprint requests: Pilgrims Corner, Pilgrims Way, Reigate, Surrey RH29LG.

Accepted 13 December 1985 the spleen showed microscopically the presence of crystals, which they also saw in the sputum of a woman with bronchitis. ${ }^{4}$ In 1860 Charcot published a more detailed description of the crystals (fig 2 ), this time his coauthor being his old student friend Edmé Felix Vulpian (1826-1887). ${ }^{5}$

These crystals were colourless and hexagonal in shape, appearing to be composed of two pyramids with their bases in apposition. Measurement nowadays shows them to be $20-40 \mu \mathrm{m} \times 2-4 \mu \mathrm{m}$. Interestingly, these crystals had been observed two years earlier, in 1851, by Friedrich Albert Zenker (1825-1898), but he did not publish his findings until $1870 .^{6}$ Nevertheless, some refer to the crystals as "Zenker's crystals." Further illustrations of these crystals, in the sputum of bronchitic patients, appeared in 1854 by August Foerster (1822-1865) ${ }^{7}$ and in 1859 by Peter Harting (1812-1885). ${ }^{8}$ The greatest English authority on asthma of the nineteenth century, Henry Hyde Salter (1823-1871), in his

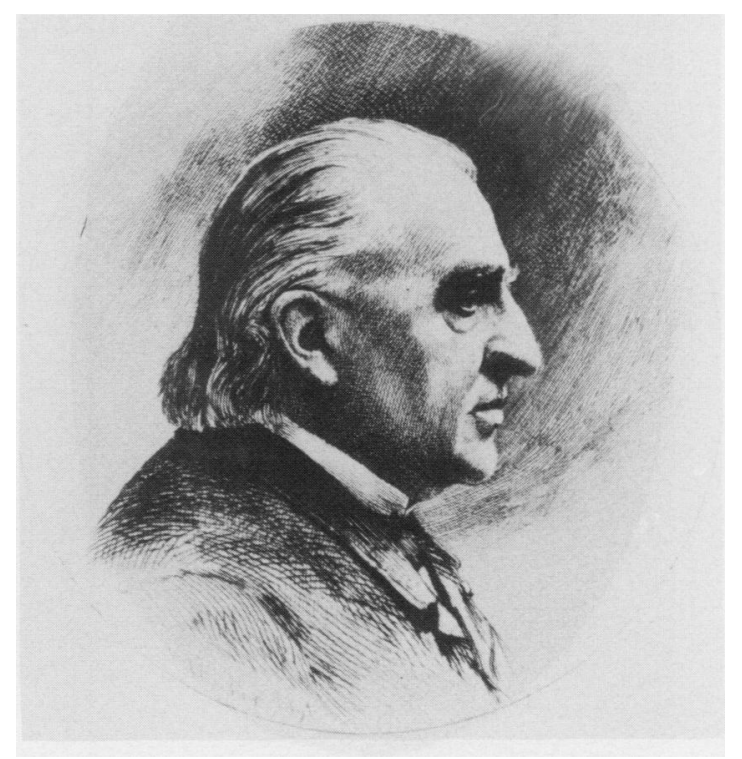

Fig 1 Jean-Martin Charcot (1825-93). 


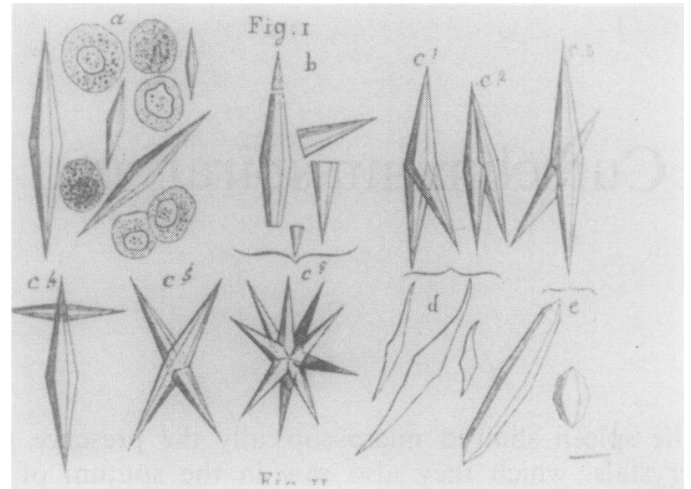

Fig 2 Charcot's crystals. (From Charcot and Vulpian, $1860 .^{5}$ )

book On Asthma (1860) included an illustration of "corpuscles" seen in asthmatic sputum, among which were objects looking like crystals; but he did not recognise or designate them as such. ${ }^{910}$

\section{Ernst Victor von Leyden (1832-1910)}

Leyden (fig 3) was born in 1832 in Danzig and in 1854 qualified MD Berlin. He served in the German army and in $\mathbf{1 8 6 5}$ was appointed professor of internal medicine at Königsberg. In 1872 he accepted a similar

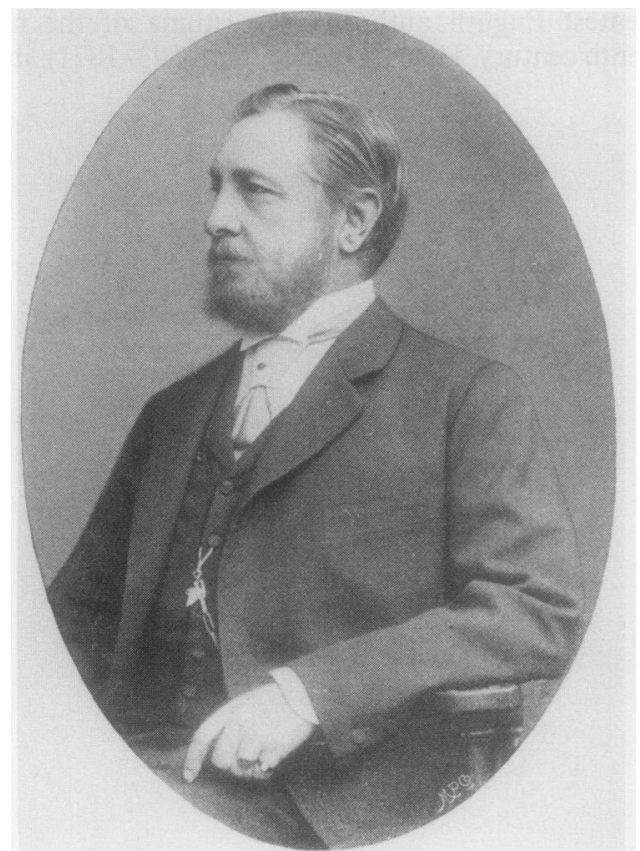

Fig 3 Ernst von Leyden (1832-1910). chair at Strasburg and in 1876 another at Berlin. $\mathrm{He} \stackrel{\stackrel{0}{\times}}{x}$ was cofounder of the Zeitschrift für Klinische $\overrightarrow{\vec{F}}$ Medizin. In 1894 he was called to Russia to attend the Czar Alexander and after this was raised to the nobil- $\frac{O}{0}$ ity. Like Charcot, Leyden later specialised in neu- $\frac{\overline{\bar{N}}}{\bar{D}}$ rology, making important contributions to the under- $\widehat{\Phi}$ standing of diseases of the spinal cord. He is considered by some to have been the first to describe ${ }^{\infty}$ myotonia congenita, although in Britain the condi- $\vec{O}$ tion is usually referred to as Thomsen's disease. ${ }^{11}$

Leyden was at Königsberg when, with his assistant $\vec{\sigma}$ Max Jaffe (1841-1911), he saw in 1870, for the first $\vec{F}$ time, crystals in the sputum of an asthmatic patient. In 1871 he drew attention to this at a medical meet- $\rightarrow$ ing, ${ }^{12}$ and in the following year he published a report iv in Virchow's Archives (fig 4). ${ }^{13}$ Fifteen years later, in 0 1886, he gave a more detailed description. ${ }^{14}$ Although aware that the crystals had been previously described by Charcot and others, he defended his claim for priority of discovery of the association of the crystals with asthma.

\section{Early theories about Charcot-Leyden crystals}

After Charcot's description of the crystals in 1853, there was considerable speculation about their nature and possible role in asthma. Charcot himself did not appreciate the special significance of the crystals in $\stackrel{\mathbb{Q}}{\Omega}$ asthma. Leyden's view was that the crystals devel- $\overrightarrow{\overrightarrow{0}}$ oped from white blood corpuscles, seen in the blood 3 and bone marrow. The presence of crystals in the sputum of asthmatic patients, however, led him to postu-

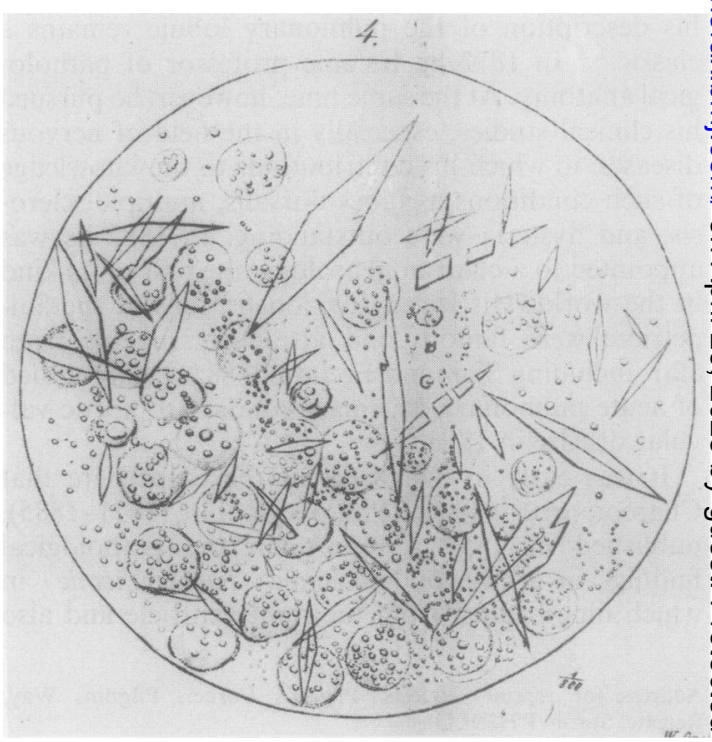

Fig 4 Leyden's crystals. (From Leyden, 1872. ${ }^{13}$ ) 


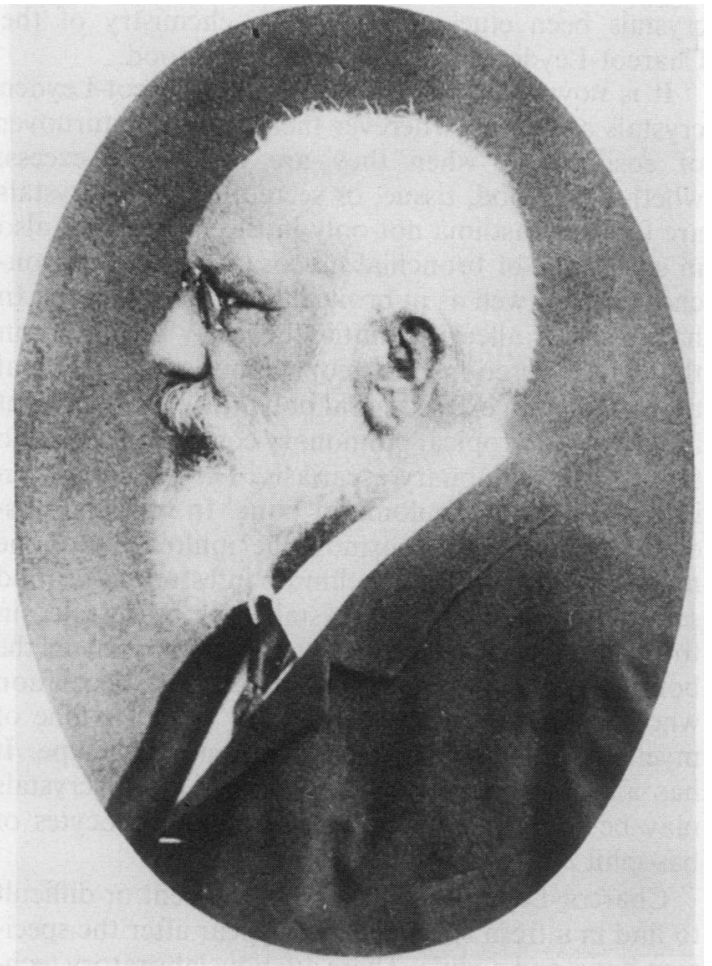

Fig 5 Heinrich Curschmann (1846-1910).

late that they could be the cause of the asthmatic attack, acting by mechanical irritation of the bronchial mucosa, which reflexly induced spasm of the bronchial muscles. In an attempt to simulate this, he carried out some animal experiments in which finely ground glass was inhaled, but this failed to provoke an asthmatic attack. These views of Leyden on the possible aetiological role of the crystals in asthma were not universally accepted - for example, Karl Störk in $1875^{15}$ and Benno Lewy in $1891^{16}$ considered that both the asthmatic attack and the formation of crystals were independent responses to some exogenous agent.

\section{Heinrich Curschmann (1846-1910)}

Curschmann (fig 5) was born in 1846 in Giessen and in 1868 qualified MD Giessen. After postgraduate work in Berlin, he moved in 1879 to Hamburg, where for the next 10 years he was director of the State Hospital. In 1888 he became Professor of Internal Medicine at Leipzig. His interests in general medicine were far ranging, as his many publications show. ${ }^{17}$

While working at Hamburg he attended the Congress of Internal Medicine at Wiesbaden in 1882, where he presented his views on Charcot-Leyden

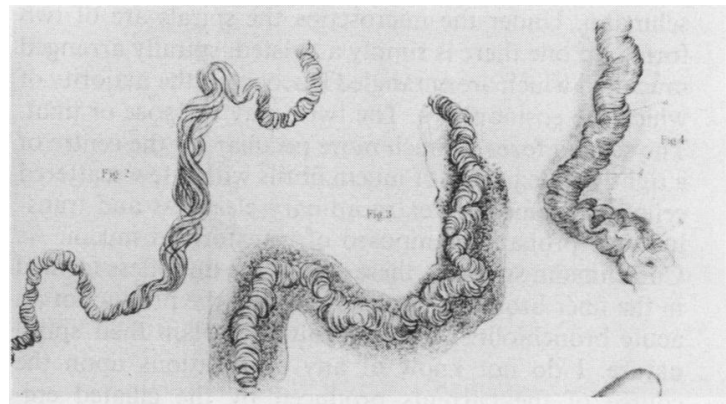

Fig 6 Curschmann's spirals. (Detail from illustration in Curschmann, 1883. ${ }^{19}$ )

crystals and described the spiral structures seen in the sputum of asthmatic patients, with which his name has ever since been associated eponymously. ${ }^{18}$

The spirals may be longer than $1 \mathrm{~cm}$, when they are easily visible to the naked eye. They are of a white or yellow colour and microscopically are seen to be composed of mucus threads, around which many fibrils appear to be bound (fig 6).

Curschmann opposed Leyden's views on the possible role of the crystals in the causation of the asthmatic attack and believed that the cause lay with the spirals, which were merely the expectorated mucinous plugs, or casts, that had blocked the fine bronchial airways and, with associated bronchial muscle spasm, were the fundamental cause of asthma. He suggested that the crystals might be a degenerate form of the spirals. In 1883 Curschmann published a more detailed description of the spirals to be found in the sputum in the variety of asthma that he preferred to call "bronchiolitis exudativa". ${ }^{19}$

At the Wiesbaden meeting in 1882 another participant, Emil Ungar (1849-1934), quite independently reported the finding of spirals in asthmatic sputum. ${ }^{20}$

As is often the case, a search of published papers has brought to light older descriptions of the spirals. As early as 1834 Amedée Lefèvre $(1798-1869)^{21}$ and in 1856 Joseph Honoré Simon Beau $(1806-65)^{22}$ had both described spirals in the sputum of asthmatic patients, Beau likening their appearance to cooked vermicelli (vermicelli cuites).

Sir William Osler (1849-1919) in the first edition of his great textbook, The Principles and Practice of Medicine (1892), had this to say of Curschmann's spirals and Charcot-Leyden crystals ${ }^{23}$ :

Often with a naked eye a twisted spiral character can be seen, particularly if the sputum is spread on a glass with a black background. Microscopically, many of these pellets have a spiral structure, which renders them among the most remarkable bodies met with in sputum. It is not a little curious that they should have been practically overlooked until described a few years ago by Cur- 
schmann. Under the microscope the spirals are of two forms. In one there is simply a twisted, spirally arranged mucin, in which are entangled leucocytes, the majority of which are eosinophiles. The twist may be loose or tight. The second form is much more peculiar. In the centre of a tightly coiled skein of mucin fibrils with a few scattered cells is a filament of extraordinary clearness and translucency, probably composed of transformed mucin. As Curschmann suggests, these spirals are doubtless formed in the finer bronchioles and constitute the product of an acute bronchiolitis. It is difficult to explain their spiral nature. I do not know of any observations upon the course of the currents produced by the ciliated epithelium in the bronchi, but it is quite possible that their action may be rotatory, in which case, particularly when combined with spasm of the bronchial muscles, it is possible to conceive that the mucus formed in the tube might be compelled to assume a spiral form. Within two or three days, the sputum changes entirely in character; it becomes muco-purulent and Curschmann's spirals are no longer to be found. They occur in all instances of true bronchial asthma in the early period of the attack. I have never seen the true spirals either in bronchitis or pneumonia. There are, in addition, in many cases the pointed, octahedral [sic] crystals described by Leyden and sometimes called asthma crystals.

\section{Charcot-Leyden crystals and the eosinophil}

It is important to appreciate that the eosinophil was unknown until it was first demonstrated by Paul Ehrlich (1854-1915) in 1879, when he introduced eosin in his technique for differential staining of white blood cells. ${ }^{2425}$ Before 1879 neither Charcot, Leyden, nor any one else could possibly have conceived a connection between Charcot-Leyden crystals and eosinophils.

When the staining of blood and sputum came into general use, it was not long before the eosinophilia seen in the blood and sputum of many patients suffering from asthma came to be recognised. In this the laboratory of Friedrich von Müller (1858-1941) of Marburg played an important part, especially the contribution of Friedrich Fink (1867-?) in his inaugural dissertation of $1890 .{ }^{26}$

Eosinophils in excess were detected also in the nasal mucosa and secretions of sufferers from hay fever. Moreover, in both asthma and hay fever the presence of Charcot-Leyden crystals was closely associated with that of eosinophils. The question that required to be answered was: what was the nature of this association?

Current understanding of the composition and role of Charcot-Leyden crystals and Curschmann spirals

Only in the past couple of decades has the relationship of the eosinophil and Charcot-Leyden crystals been elucidated and the chemistry of the Charcot-Leyden crystal protein understood.

It is now generally accepted that Charcot-Leyden crystals are found wherever there is a large turnover of eosinophils, when they are present in excess, whether in blood, tissue, or secretions. Thus crystals are found in asthma not only in the sputum but also in specimens of bronchial mucosa removed at bronchoscopy, as well as in bronchial lavage washings. In hay fever, or allergic rhinitis, they may be present in the nasal secretions, in biopsy specimens of nasal mucosa, and in excised nasal polypi. They are present in the lung in tropical pulmonary eosinophilia (due to filaria) and pulmonary ascariasis. They are also seen in eosinophilic granuloma of bone. In intestinal disease, where there is eosinophilic infiltration of the mucosa (for example, in helminth infestations or food sensitivity reactions) the crystals may be detected in the stools. In leukaemia they may be present in the bone marrow, and it is a matter of speculation whether Charcot's original case in 1853 was one of myeloid leukaemia of the rare eosinophilic type. It has also been shown that Charcot-Leyden crystals may be found in relation to granular leucocytes of basophil type. ${ }^{27}$

Charcot-Leyden crystals may be absent or difficult to find in a fresh specimen but appear after the specimen has stood awhile. There are now laboratory techniques whereby crystals may be readily formed in vitro by lysing the eosinophils, although this is possible only in primates - the eosinophils of guineapigs behave differently and do not produce crystals.

The chemical composition of the crystals has proved difficult to unravel. In 1856 Jean Baptiste Vidal (1825-1893) ${ }^{28}$ maintained that the crystals were haematoidin; in 1864 Nikolaus Friedreich $(1825-1885)^{29}$ considered them to be tyrosine. The semen and tissue of the testis occasionally contain microscopic crystals known variously, by the names of their describers, as the crystals of Neumann, Reinke, or Lubarsch. These crystals are composed of spermine phosphate and it has been suggested that this is also the substance of which Charcot-Leyden crystals are formed. There is, however, no basis for this and the two varieties of crystal are quite distinct.

Recent research, however, has shown that CharcotLeyden crystals are composed of an acidic protein, of molecular weight about $13000 .{ }^{30}$ Radioimmunoassay has enabled its detection in blood serum. ${ }^{31}$ This protein is largely, if not entirely, lysophospholipase (phospholipase B), the function of which is to inactivate lysophospholipid. ${ }^{32}$ The role of lysophospholipids and lysophospholipases in human disease is still little understood. Lysophospholipids exist in many-mammalian tissues, located in the cell membrane, where their biosynthesis and degradation 
are carefully balanced. They possess a toxic action on cells-for example, they may produce haemolysis. Lysophospholipases are the enzymes that degrade lysophospholipids, by catalysing the hydrolysis of acyl ester bonds. They are also implicated in prostaglandin metabolism. ${ }^{33}$ The role that lysophospholipase have in asthma remains a matter for speculation.

Curschmann spirals are now known to be composed chiefly of glycoprotein, and often contain eosinophils and Charcot-Leyden crystals; lysophopholipase has been found in spirals.

The actual source from which the Charcot-Leyden protein is derived has been variously described as being the nucleus, cytoplasm, or membrane of the eosinophil cell, but there is now little doubt that it arises from the granules. When these fragment, the protein is extruded and this forms the nidus around which the crystal develops. ${ }^{34}$

\section{Conclusion}

Although virtually every textbook of medicine and monograph on asthma during the past century have made reference to the presence of Charcot-Leyden crystals and Curschmann spirals in the sputum of asthmatic patients, it must be admitted that at the present time, when there are so many other aids to diagnosis, these constituents of the sputum are no longer of major diagnostic importance to the practising physician or pathologist.

It is now accepted that there is nothing pathognomic about the crystals, which may be present in any condition or site where there is excessive turnover of eosinophils-and, rarely, of basophils.

I wish to express my thanks to Professor Hans Schadewaldt of Düsseldorf, whose Geschichte der Allergie (München: Dustri-Verlag Dr Karl Feistle, 1983) has proved to be an invaluable source of reference and who kindly agreed to the reproduction of the three portraits (figs 1,3 , and 5).

\section{References}

1 Charcot J-M. Maladies des poumons et du système vasculaire. Cours d'anatomie pathologique de la Faculté de Médecine. Paris, 1877-8.

2 Miller WS. The lung. 2nd ed. Springfield: Thomas, 1947:189-91.

3 Guillain G. J-M Charcot 1825-1893: his life-his work. New York: Hoeber, 1959.

4 Charcot J-M, Robin CP. Observations de leucocythémie. Comptes Rendus Soc Biol 1853;5:44.

5 Charcot J-M, Vulpian EFA. Note sur les cristaux particuliers trouvés dans le sang et les viscères d'un sujet leucémique. Gaz Méd 1860;7:755.

6 Zenker FA. Charcotsche Kristalle im Blut und Gewebe leukämischer und in den Sputis. Deutsch Arch Klin Med 1870;18:125.

7 Foerster A. Atlas der Microskopischen Patholigschen
Anatomie. Leipzig, 1854:67.

8 Harting P. Das Microskope. Braunschweig, 1859:458.

9 Salter HH. On asthma: its pathology and treatment. London: Churchill, 1860.

10 Sakula A. Henry Hyde Salter (1823-1871): a biographical sketch. Thorax 1985;40:887-8.

11 Pagel J. Biographisches Lexicon. Berlin: Urban und Schwarzenberg, 1901:1002-3.

12 Leyden E von. Zur Kenntnis des Bronchialasthmas. Tagbl Vers Deutsche Naturl Ärzte 1871;44:24.

13 Leyden E von. Zur Kenntnis des Bronchialasthmas. Archiv Path Anat 1872;54:324.

14 Leyden E von. Über Bronchialasthma. Deutsch Mil Ärzte Z 1886;15:516.

15 Störk K. Mittheilungen über Asthma bronchiale und über die mechanische Lungen behandlung. Stuttgart, 1875.

16 Lewy B. Über das Verkommen der CharcotLeydenschen Krystalle in Nasentumoren. Berlin Klin Wschr 1891;28:816, 845.

17 Pagel J. Biographisches Lexicon. Berlin: Urban und Schwarzenberg, 1901:362-3.

18 Curschmann H. Uber die Bedeutung der Leyden'schen Krystalle für die Lehre vom Asthma bronchiale. Verh Deutsch Ges Inn Med 1882;1:191.

19 Curschmann H. Uber Bronchiolitis Exsudativa und ihr Verhältnis zum Asthma nervosum. Deutsch Arch Klin Med 1883;32:1.

20 Ungar E. Uber die Bedeutung der Leyden'schen Krystalle für die Lehre vom Asthma bronchiale. Verh Deutsch Ges Inn Med 1882;1:162.

21 Lefèvre A. De l'asthme: recherches médicales sur la nature, les causes, et le traitement de cette maladie. Paris, 1847.

22 Beau JHS. Traité clinique et expérimental d'auscultation appliqué à l'étude des maladies du poumon et du coeur. Paris, 1856:126.

23 Osler $\mathrm{W}$. The principles and practice of medicine. 1st ed. London: Pentland, 1892:499-500.

24 Ehrlich P. Uber die Specifischen Granulation des Blutes, 1879. In: The Collected Papers of Paul Ehrlich. Vol 1. London: Pergamon, 1956:117.

25 Ehrlich P. Beiträge zur Kenntnis der granulierten Bindege-Webszellen und der eosinophilen Leukocythen. Arch Anat Physiol 1879;3:166.

26 Fink F. Beiträge zur Kenntnis des Eiters und des Sputums. (Med Inaug Diss.) Bonn, 1890.

27 Ackerman SJ, Weil CJ, Gleich GJ. Formation of Charcot-Leyden crystals in human basophils. J Exp Med 1982;155:1597.

28 Vidal J-B-E. De la leucocythémie splénique, ou de l'hypertrophie de la rate avec alteration de sang consistant dans une augmentation considérable du nombre des globules blancs. Gaz Héb Med 1856;3:254.

29 Friedreich N. Beiträge zur Kenntnis der Sputa: Tyrosin kristalle im Auswarf. Arch Pathol Anat 1864;30:381.

30 Archer GT, Blackwood A. Formation of CharcotLeyden crystals in human eosinophils and basophils and study of the composition of isolated crystals. J Exp Med 1965;122:173.

31 Ackerman SJ, Loegering DA, Gleich GJ. The human eosinophil Charcot-Leyden crystal protein: biochemical characteristics and measurement by radio-immune assay. J Immunol 1980;125:2118-26.

32 Weller PF, Austen KF. Human eosinophil lysophospholipase: the constituent of Charcot-Leyden crystals. J Allergy Clin Immunol 1981;67:15.

33 Bosch H van den. In: Hawthorne JN, Ansell GB, eds. Phospholipids. Amsterdam: Elsevier, 1982:313-434.

34 Weiss EB, Segal MS, Stein M. Bronchial asthma. 2nd ed. Boston: Little, Brown, 1985. 